\title{
Implementing marketisation: comparing Irish activation and social housing
}

\section{Mary P. Murphy \& Rory Hearne}

To cite this article: Mary P. Murphy \& Rory Hearne (2019) Implementing marketisation: comparing Irish activation and social housing, Irish Political Studies, 34:3, 444-463, DOI: 10.1080/07907184.2019.1583215

To link to this article: https://doi.org/10.1080/07907184.2019.1583215

曲 Published online: 05 Mar 2019.

Submit your article to this journal $\pi$

Џll Article views: 309

Q View related articles $₫$

View Crossmark data

4 Citing articles: 2 View citing articles 


\title{
Implementing marketisation: comparing Irish activation and social housing
}

\author{
Mary P. Murphy ${ }^{a}$ and Rory Hearne ${ }^{b}$ \\ ${ }^{a}$ Department of Sociology, Maynooth University, Co Kildare, Ireland; ${ }^{b}$ Department of Applied \\ Social Studies, Maynooth University, Co Kildare, Ireland
}

\begin{abstract}
This paper contributes to the analysis of policy making processes in the Irish context. It offers original insights into recent policy changes in Irish activation and social housing policy which, over the period of austerity, were subject to significant institutional reshaping and structural reforms including marketisation. A three I's framework tracing the interaction of key ideas, institutions and interests isolates dynamics informing the implementation of marketisation in these sectors and allows insights into how policy is shaped by key variables including markets, civil society and international actors. Attention is drawn to the different pathways to, and implementation of, marketisation in the different sectors. Marketisation reforms were largely implemented in PES and activation reforms, but marketisation pathways had different fortunes when it came to meeting social housing need. The paper explores why this is the case and suggests issues of scale and degrees of financialisation are important factors informing different pathways to and experiences of marketisation of social policy, with, in both sectors, important consequences for social policy and human rights. Issues of ideology, centralisation, international f(actors), timing and scale are important variables in shaping different pathways to marketisation with consequences for likelihood of political resistance to such processes.
\end{abstract}

KEYWORDS Marketisation; Ireland; ideas; institutions; interests; social policy

\section{Introduction}

This paper contributes to the analysis of Irish policy making processes in the Irish context with original insights into recent policy changes in Irish activation and social housing policy. Using a three l's framework to trace the interaction of key ideas, institutions and interests we isolate dynamics informing two key policy decisions over the period 2012-2016 and compare the politics of marketisation across the two sectors. Following Hall and Taylor (1996) and Hay (2004), the three I's framework privileges neither institutions, interests nor ideas as the driving forces of change but examines the interaction of the 
three variables to isolate how different forms of power are utilised in international and domestic decision-making processes and across different stages of the policy cycle and the political cycle. This gives us insight into recent processes of public sector institutional reform in Ireland and how they were shaped by different types of variables, ideas, interests and institutions, including markets, civil society and international actors. The Irish welfare state, in common with welfare states across Europe, is confronted with a number of crucial challenges (Murphy \& Dukelow, 2016). Over the economic crisis Ireland experienced significant spending cuts. Economic collapse saw unemployment rise from $4 \%$ to $15 \%$ alongside increased poverty and a range of negative social impacts (Hardiman \& Regan, 2012). Alongside this, social disinvestment in housing sparked a severe social housing crisis and, for the first time, a significant family homelessness crisis (Dublin Regional Homeless Executive [DHRE], 2017). Over the period, labour activation or public employment services (PES) and social housing policy were subject to significant institutional reshaping and structural reforms including marketisation. Delivery in both sectors was marketised through use of various mechanisms including pay by results, commissioning, tendering, private sector rental subsidies and tax incentives, and use of public-private partnerships (Murphy \& Dukelow, 2016; Norris \& Byrne, 2016). This paper is concerned with the internal dynamics shaping these two examples of recent Irish welfare state change and marketisation, and the differing experiences of pathways to, and implementation of, marketisation (Elsinga, Stephens, \& Knorr-Siedow, 2014). Following Shearer, Abelson, Kouyaté, Lavis, and Walt (2016), we use process tracing in a comparative case study utilising policy documents and indepth interview data to examine the two cases. Essentially marketisation reforms were largely implemented for both PES reforms and social housing, but marketisation pathways have had consequences for social rights in both cases.

The first case concerns the institutional reform of labour activation policy (PES) including the development of new quasi-markets for PES (Taylor, Rees, \& Damm, 2016). The second case refers to the reform of private rental subsidies from a residual or secondary policy towards a primary marketised model of social housing provision. We proceed by outlining how we use and understand key concepts and our conceptual and methodological approach (Section 2). We then discuss the key changes to labour activation (Section 3) and social housing policy (Section 4). We follow this by outlining institutional (Section 5), ideational (Section 6) and interest (Section 7) based accounts of change in both policy areas. Section 8 discusses key observations on the different pathways to marketisation in both sectors. Finally we conclude issues of centralisation, international, timing and scale are important variables in shaping different pathways to marketisation. 


\section{Conceptual framework and methodology}

We first conceptually clarify our use of distinct terms utilised in the paper, namely privatisation, marketisation and quasi-markets and financialisation. We avoid using these distinct terms as interchangeable but do see them as interrelated, one process can lead to another, for example quasi- markets can shift to full marketisation or ultimately financialisation. Privatisation, or asset disposal, occurs when the state's ownership of corporate entities is (partially) reduced (Hermann, 2007). For the purposes of this paper we understand marketisation as a trend towards using an open price mechanism to operationalise supply and demand. This occurs when welfare is commoditised and given a market value, as occurred internationally with both social housing and activation services (Elsinga et al., 2014; Grover, 2009; OECD, 2009). We understand quasi-markets as planned and internal public sector institutional structures that have some market features but where state imperatives enable or restrict the extent of its full functioning (Wiggan, 2015). The process can entail use of outscourcing, commissioning and procurement, concessions, delegated management contracts, service level agreements (SLAs) leasing, and PPPs. Market concepts like competition can also be implanted, through new public management techniques, into the public sector transforming how welfare is delivered and paid for (Greve, 2015). The financialisation process, understood as the expansion of financial markets, agents and motives (Epstein, 2005) was actively promoted by European integration. van der Zwan (2014) describes how intensification of finance and capital flows means increased influence of global capital on national priorities as seen in new regimes of accumulation, shareholder value orientation and the financialisation of everyday life, all three are features of the Irish housing system and policy (Hearne, 2017).

The financialised form of globalisation is of great significance in a small open economy over-dependant on foreign direct investment. However finance is mediated in different ways into domestic policies and is a more salient driver in some welfare areas than others (Murphy \& Dukelow, 2016). The crisis is associated with a marked intensification in Ireland of quasi-markets in, not only activation and housing, but also in policy debates concerning water, health and pensions. The overall ideational preference of the state is for enhancing market led welfare provisions however not all policy decisions to create quasimarkets succeed; Irish proposals for a private universal health care system failed to progress and attempts to fully commodify water policy were abandoned (Murphy \& Dukelow, 2016). Much can be learned about how marketisation is shaped and progresses in different social policy sectors (Koppe, 2012).

The Irish welfare state is hybrid in nature. While frequently classified as liberal with strong market reliance, it also exhibits strong secondary Christian-democratic principles associated with Catholicism, corporatism and 
mixed delivery of welfare services (Ferragina \& Seelieb-Kaiser, 2011). This history of liberal and mixed delivery of welfare might suggest Irish welfare was a likely candidate for marketisation of welfare services, but how might this happen in different sectors? Explaining or understanding complex policy change like marketisation requires integration of multiple policy theories. Following Shearer et al. (2016, p. 1200) we use the '3ls' as a theory of policy change to explain the dynamics of marketisation essentially incorporating all possible explanatory variables' within the '3ls' framework. The approach Table 1 (below) involves distilling accounts of policy change frameworks into three key elements, or explanatory variables known as the '3ls: formal and informal domestic and international institutions (rules of the game including processes, context and policy path dependence); interests (domestic and international actors, preferences and power resources) and ideas (domestic and international content, evidence, expert knowledge, framing, values, and norms), (Hall \& Taylor, 1996; Hay, 2004; Pomey et al., 2010; Shearer et al., 2016). Interests, ideas and institutions are over-arching categorical variables, within which substantive variables such as international actors or institutions and rights or markets discourses can be located. This framework is applicable at all stages of the policy cycle, we attempt to apply from the point of policy formulation over a stage of policy making and a range of the process. Such application to a non-static policy process is challenging, the policy cycle is not linear as policy science might suggest. We proceed to trace key features of marketisaiton in both sectors drawing from document analysis and a range of qualitative interviews with policy and delivery actors in both sectors which took place over 2017 and 2018.

\section{Creating markets for public employment services}

From 1985 Irish PES were delivered through a quasi-autonomous government organisation FÁS, the national training authority. While in theory a national

Table 1. Timelines and pathways in two activation and social housing sectors.

\begin{tabular}{|c|c|c|}
\hline Theme & PES & Social housing \\
\hline Proposed change & $\begin{array}{l}\text { Activation and quasi } \\
\text { market }\end{array}$ & Shift to HAP and use of market \\
\hline Status quo at start of process & State only PES actor & State primary social housing provider \\
\hline Policy discussion date/ref & $\begin{array}{l}\text { Pathways to Work 2012- } \\
2016 \\
\text { JobPath tender } 2012\end{array}$ & $\begin{array}{l}\text { Social Housing Supply Support Refor (2014), } \\
\text { HAP pilot (2014), Rebuilding Ireland (2016) }\end{array}$ \\
\hline $\begin{array}{l}\text { Institutions and governance } \\
\text { domestic international }\end{array}$ & $\begin{array}{r}\text { Troika, Labour Market } \\
\text { Council, DSP/DEASP }\end{array}$ & $\begin{array}{l}\text { Dept of Environment, Dept of Housing, Local } \\
\text { Authorities }\end{array}$ \\
\hline $\begin{array}{l}\text { Interests and actors, } \\
\text { domestic international }\end{array}$ & $\begin{array}{l}\text { Bureaucrats, NGOs, NESC, } \\
\text { OECD }\end{array}$ & SLA contractors, CIF, REITS \\
\hline Ideas domestic international & $\begin{array}{l}\text { Rights, Obligations, } \\
\text { Commissioning }\end{array}$ & $\begin{array}{l}\text { Right to a Home } \\
\text { Market efficiency }\end{array}$ \\
\hline
\end{tabular}


PES, FÁS focused on providing direct services for the unemployed and a range of active labour market programmes. Boyle (2005) likened FÁS to a Swiss Army knife, able to deliver a myriad of functions but performing none of them particularly well. Its lack of functional employment services failed to win the confidence of employers who preferred to use the services of privatised recruitment services and agencies. However it also failed to effectively engage unemployed people with appropriate supports leading the OCED (Grubb, Singh, \& Tergeist, 2009) and McGuinness, O'Connell, Kelly, and Walsh (2011) to label Ireland a 'laggard' in relation to activation. The pressure of the economic crisis overlapped with a FÁS corporate governance scandal giving a unique activation reform opportunity for various actors, particularly the Department of Social Protection (DSP) (Dukelow, 2016; O'Connell, 2016).

The primary crisis period innovation in Irish labour activation was Pathways to Work (PTW) 2012-16 (Department of Social Protection [DSP], 2012) which merged DSP income supports and FÁS employment services into a new stateled PES Intreo. The major reform occurred in the context of a six-fold increase in claimants and consequent acute pressure to provide both PES and income supports. The significant reform redeployed 1,300 civil servants into DSP, and merged 700 FÁS personnel and functions into DSP along with the incorporation of 1,000 additional Community Welfare Officer's (CWO's). Over four years 60 new one-stop-shop type local Intreo offices were opened with merged income supports and PES functions, this was supported by refurbishment, new IT systems, training, and cultural change programmes ( $\mathrm{O}^{\prime} \mathrm{Connell}$, 2016). While issues of culture, competence and capacity remain, it is recognised that the scale of reform was historically immense in the Irish context with key output targets realised over the reform period (Martin, 2014; NESC, 2013).

We draw attention here to three forms of marketisation evident in Irish PES. The first and most obvious marketisation strategy centred on the deliberate construction of quasi-markets in PES. To meet ongoing capacity and alleviate pressure on activation services a Pay by Results private delivery model JobPath was first mooted in 2011 and became a reality in 2015. JobPath, PES for the long term unemployed, was created by direct tendering of PES delivery contracts to international prime companies. The speed of implementation far exceeded the pace of privatisation in UK and Australia causing anxiety for some that it was too quick. Given fears the Irish market might not be sufficiently large to attract primes, contracts were shared between two private sector companies with near monopoly like delivery responsibility for half the country each. Wiggan (2015) notes that the quasi-market contract for these services was a marked improvement on the UK Work Programme and contained elements of social democratic policy and practice, however recent government analysis questions the lack of evidence base for evaluating PES (Lavelle \& Callaghan, 2018), there have been less sustainable employment 
outcomes than anticpated. Privatisation was challenged by two public sector unions however the Civil Service Arbitration Board ruled DSP had followed adequate consultative procedures to outsource services. The challenge provoked little public reaction and JobPath originally proceeded with little fuss, albeit by 2018 there were signiifcant concerns about welfare conditinality and sanctions, transparency, data protection and value for money such that in 2019 a parliamentary motion called for its aboliiton (Oireachtas, 2019). This process of outsourcing to the private sector is nowhere near financialisation, but internationally, employment services are the subject of the 'postFordist search for new capitalist markets', albeit not to the scale as is possible in housing markets (Grover, 2015).

A second form of marketisation of activation was the application of commissioning processes, tendering and SLAs to replace traditional block grant funding models used with not-for-profits delivering activation and commuity dvelopment related services. This occurred through a 2015 commissioning process for the Social Inclusion Community Activation Programme and through shifts from block grants to Service Delivery Agreements for Local Employment Services and Jobs Clubs (Meade, 2017). These measures were and remain controversial and interviews suggest that, consistent with experience in the UK, commissioning is associated with shifts towards a competition culture in sectors that were strongly collaborative (Taylor et al., 2016). It is anticipated that Local Employment Services and Job Clubs will travel further along the path of quasi marketisation and come under a pay-byresults regime in 2020. In January 2019 DEASP announced plans to issue a new Request for Tender for PES for both the long-term unemployed and those more distant from the labour market. In 2017 these quasi-market forms of PES (Job Path, LES, and SICAP) amount to $€ 165 \mathrm{~m}$ per annum of corporate welfare spread across both profit and not for profit sectors. Interviews suggest funding uncertainty and vulnerability has impacted on organisational moral, work conditions and quality of services, particularly amongst smaller community based organisations. The third form of marketisation is the choice of the state to continue to deliver only a residual PES ring-fenced for the use of job seeker claimants, leaving the wider function of employment services to the market and to national and international private sector recruitment agencies who turned over $€ 1.73$ billion in 2013 (Taylor, 2015). While under pressure from direct online and platform recruitment, having recovered from a recession slump, the sector is buoyant. Such agencies, through the National Recruitment Federation of Ireland, play direct and indirect roles in Irish labour market policy, lobbying on labour legislation, determining who gets jobs and in particular influencing the balance to which labour and skills needs or shortages are addressed through indigenous labour supply or migrant labour. 


\section{Creating markets for social housing}

Bentgsson (2001) reminds us that housing can be distinguished from other welfare policies to the degree that the state is rarely the main mechanism of housing distribution. Housing has always been understood as an individual market commodity while also as a public good demanding state investment and regulation. The Irish state traditionally played a significant role in the delivery of social housing for both rent and ownership. While the policy has shifted over decades the adoption of the market as the primary mechanisms to deliver Irish social housing is made very explicit in recent housing policy.

Throughout most of the twentieth century the Irish state played a central role in the provision of state-supported socialised home ownership with a 'protected' social complement to the general housing market (Bentgsson, 2001). From as early as the 1970s the Irish state had shifted towards market delivery opting to secure some market provision of social housing through PPP's (Hearne, 2017) and increased use of private rental subsidies. The first private rental subsidy the 1974 Rent Supplements (RS) was understood primarily as a short term income support and administered by the DSP. However by 2003 a Rental Assistance Schemes (RAS) was introduced as a social housing support administered by the local authorities. The global financial crisis impacted significantly causing inter alia, a house price crash and the collapse of the housing market along with a growth in numbers waiting for social housing and a sharp rise in family homelessness as an austerity regime decimated the capital budget for social housing construction reducing it by $80 \%$. We draw attention here to three pathways to marketisation of Irish social housing policy.

Overall we see what Minton (2016) describes as a shift from 'bricks to benefits' with significant disinvestment in direct build social housing from 8,794 social housing units in 1975, 5,559 in 2005 to only 75 in 2015 (Hearne \& Murphy, 2017). Since 2011 private rental subsidies have shifted from secondary to primary social housing delivery mechanisms. The key document Social Housing Strategy 2020 Support, Supply and Reform (Department of Housing Environment and Local Government [DHELG], 2014, p. 5) committed the State to a central role in the direct provision of social housing 'through a resumption of building on a significant scale' with a commitment to 35,000 new social housing units, over a 6 year period, while also committing to support up to 75,000 households through an enhanced private rental sector using the private rental subsidy Housing Assistance Payment (HAP), a pilot of which had commenced that year. By 2016 Rebuilding Ireland (DHPLG, 2016) consolidated dependence on the market to deliver private rental accommodation to cover both non-social and social housing with HAP now the primary social housing mechanism. Access to private rental accommodation is more difficult in the context of a growing gap between state 
housing support rent limits and market rents. Under the new HAP, mainstreamed over 2014-2017, eligible households source their own accommodation in the relatively insecure private rented sector and make their own tenancy agreement with the landlord. Vulnerable low-income families prefer the security of tenure offered in more traditional social housing. HAP housing does not satisfy social housing need or the right to housing. HAP is an insecure form of housing reliant on private rental leases, tenants are vulnerable to eviction (Hearne \& Murphy, 2018). They not only experience discrimination but cannot compete for a HAP tenancy in a tight private rental market increasingly exposed to a financialised global economy (Norris \& Byrne, 2016) Tight private market supply and rising rents caused an increased loss of tenancies especially among low-income households, contributing to the new phenomena of family homelessness (Hearne \& Murphy, 2018).

HAP also provides a second significant pathway to marketisation in the form of a $€ 500$ million pa corporate subsidy to private landlords, which Burke Kennedy estimates amounts to an estimated $€ 3 b$ per annum subsidy over the next five years by 2021 (2017). The Irish Government Economic and Evaluation Service (2017) determined HAP does not return value for money in the context of tight housing market supply. Use of HAP and marketised delivery of social housing has to be placed in the context of the degree to which financialisation of housing and property was a key strategy of the Irish state to deal with the 2008 financial and property crash. These subsidies function to enable landlords survive high levels of mortgage arrears for buyto-lets and keep many landlords afloat, thus shoring up Ireland's financial institutions and economic model. Various government policies have proactively encouraged investors and speculators, global equity investor, vulture funds, and Real Estate Investment Funds (REITS), to invest in distressed Irish housing and property and related loans (Hearne, 2017). In order to 'facilitate the attraction of foreign investment capital to the Irish property market' government made REIT rental profits exempt from corporation tax in 2013 (Noonan, 2013). Rental subsidies also provide an economic floor for institutional investors, guaranteeing a base line return on investment, thus reinforcing the profitability of the Irish private housing market as a site for international investors and contributing significantly to the dynamic of house price increases, IRES (REIT) for example demonstrate a 7\% return on investment in one property portfolio of 27 units in Hansfield West Dublin all of which have been rented to previously homeless tenants accessing HAP. Investor purchases amounted to $38 \%$ of all buyers in the first quarter of 2017, up from just 21\% in 2010 (Hearne, 2017).

A third pathway to marketisation has been the increased use of SLA's to fund delivery of homeless services by housing associations, non-government organisations (NGO's) and charities. As elsewhere use of SLAs is associated with greater use of managerial governance techniques which, over time, 
shift the culture and modus operandi of housing and other NGO's. Interviews reveal that historically the approach was to price the homeless service SLA's below the economic cost of the service with homeless providers competing on non-cost sectors and implicitly agreeing to cross subsidise the delivery of the service. New business models mean that this traditional commissioning model has evolved as some NGOs have moved into a process of competitive bidding wars for contracts that are already priced below cost, a clear case of a race to the bottom. A second feature of SLA's has been the curtailment or outright prohibition of advocacy by funded organisations. Interviews suggest that, for some, this led over time to an inhibition or suppression of campaigning, which in turn caused new dynamics or tensions between these NGO's and housing activists and social movements, albeit some homeless organisations are also strong advocates.

In labour activation reforms were largely implemented, quasi-markets for PES (Job Path) have been established, and SICAP procurement processes are well into their second cycle, however it is not clear how or whether these reforms have contributed to falling unemployment. Conversely while HAP is now the primary social housing vehicle social housing targets have not been reached and market derived forms of social housing have been insufficient to resolve homelessness. To discuss further the similarities and differences between the pathways and different experiences of marketisation in the two sectors in the next three sections we use the 3l's framework to compare the interaction of institutions, ideas, and interests across the two sectors.

\section{International, national and local institutions}

Institutions are 'the formal and informal rules, norms, precedents, and organisational factors that structure political behaviour' (Pomey et al., 2010). The governance and institutional policy framework for activation differed from housing in a number of respects and these differences are evident at international, national and local levels.

The Irish political institutional context is a policy culture aligned to progressive incrementalism and consensus policy making. Implementation paralysis is common, often policy does not translate into practice. Ireland has a centralised governance structure with a strong cabinet and weak parliament, and Irish local government is among the weakest in Europe. The Proportional Representation Single Transferable Vote electoral system is associated with a localist and clientalistic political culture which, at least until the crisis, was dominated by a 2.5 party system of centrist parties. Ireland has a number of veto points including a bicameral parliament, a corporatist type social partnership and a written constitution. However despite a written constitution, it only weakly articulates social and economic rights to 
work or housing so that in legal terms Irish welfare rights are relatively residual (Bentgsson, 2001). One of the first consequences of the crisis was the 2009 collapse of existing national wage agreements, following which Ireland's social partnership institutions were formally dissolved in 2011, to some degree removing traditional veto points from the policy infrastructure. However personal networks and relationships (some two decades long) survived and maintained a policy consensus during this period and public sector binding arbitration mechanisms were is use. Power was to a large degree centralised over the period of crisis with the Trioka working through the Economic Management Council, (comprised of Ministers of Public Expenditure and Reform, Finance, the Prime Minister (Taoiseach) and Deputy Prime Minister (Tánaiste)).

Pathways to Work, the main PES policy document, was largely a domestic initiative but was institutionally embedded in the Troika programme (Ireland, 2010) with quarterly targets and well-defined implementation metrics. DSP reported implementation progress to a new institution, the Labour Market Council established in 2013 (LMC, 2014). With no local government role in delivering policy, there was a strong top-down vertical governance. Decision making was enacted at cabinet level and its implementation monitored through a cabinet subcommittee, interviews suggest the Taoiseach's and Tánaiste's leadership was considered crucial.

The governance and institutional policy framework for Rebuilding Ireland, Ireland's main housing strategy, differed substantially as the core annual national targets for both social housing and private rental sector subsidies and their delivery was dependant on local authorities and housing associations. This suggests the domestic institutional actors such as the Department of Housing and the Government was key in marketisation policies. While the HAP targets have largely been met thus far in terms of accessing social housing from the private rental sector, the minimal social house building targets set out in Rebulding Ireland have not been met. Local authorities, reeling from austerity era budget cuts and recruitment embargos, had little capacity to meet targets. Housing construction requires a significant lead-in time to develop resources, staffing and administrative systems, such that targets have not been met and implementation remains slow and inconsistent. Despite the post-2013 economic recovery, capital funding for direct social housing building by local authorities and housing associations continued to be restrained by central government who in turn are restrained by EU fiscal rules. While the Rebuilding Ireland targets are reported to national parliament the post-2016 minority government is arguably less cohesive than the previous unified government which showed strong leadership implementing activation reforms.

The EU Open Method of Co-ordination has had some influence on national employment policies (De la Porte \& Pochet, 2012). The Troika's interest in activation policy had two significant domestic impacts. The first was the prioritisation of activation reforms amongst the domestic political elite and a clear 
politically relevant reporting cycle. The second, a dampening of the power of domestic veto points and players that overcame a strong Irish tendency towards 'policy implementation paralyses. Interviews with senior civil servants suggest it is in implementation rather than the initiation or design of activation reforms that the influence of the international is most powerful. In contrast the Troika influence on social housing policy is largely filtered through activation reforms which sought to remove poverty traps through the new HAP private rental sector subsidy. There is little evidence of direct international input into housing policy. Housing is not an EU competence and the EC Social Investment Package homeless analysis is largely invisible in the policy process. However, European Central Bank lending rules and overall fiscal policy expenditure thresholds do partially impact on, and are used by the government to legitimate, the lack of investment in capital funding for social housing.

\section{Interests}

Interests refer to 'agendas of societal groups, elected officials, civil servants, researchers, and policy entrepreneurs' (Pomey et al., 2010, p. 709). Because welfare state projects are often explained as outcomes of left-dominated governments we start by examining Irish political cleavages. Ireland was traditionally a two and half party system with a pro-business Fine Gael (FG), a populist Fianna Fail and small Labour Party (LP) but the crisis caused a significant fracturing of the old system without yet creating a clear new cleavage. FG, in power for the whole of the period under review are associated with light regulation, low tax competition, and ideological orientation towards privatisation and a more conditional approach to social policy. In power with Labour since 2011, FG suffered a resounding electoral defeat in 2016 losing 26 of its 77 seats. However FG retained power in a minority government propped up by independents and a confidence and supply agreement with the second largest party FF. FF regard themselves as a republican party, they had been in power for the fifteen years leading up to the economic crisis and were decimated in the 2011 General Election. Entering the 2016 general election with a 'fairness' rhetoric but a policy platform consistent with a neoliberal political economy model, they regained enough seats to become the second largest party and enter the confidence and supply agreement in 2016 (effectively acting as government and opposition).

Somewhat counter-intuitively the Irish left has not fared well over the crisis and experienced a redistribution of votes within the left more than a movement of votes to the left, as well as a shift in votes to a number of new left political actors including independent (non-party) representatives. The Labour Party, the junior 2011-2016 coalition partner, having directly implemented cuts that hurt vulnerable groups, lost 25 of its 32 remaining 
seats (a new party, the Social Democrats returned their existing 3 seats in 2016). Other left parties gained from alignment with the anti-austerity social movement, the Right2Water campaign, which emerged in 2014. These included, Sinn Fein, a nationalist republican party which increased its seats from 14 to 23. The radical United Left Alliance who entered the 2011 parliament with seven seats, after a number of splits and defections, registered as a political party AAA-PBP and won 6 seats in the 2016 GE. The net shortterm effect of this political and social turbulence has been the dominance of the centre-right in government and, various interviews suggest, an ideological shift towards marketisation. The continued fractured existence of the left and new social movements means a potentially less coherent opposition to marketisation albeit various interviews point to the success of the water movement, and by 2018 there is significant mobilisation and civil society coalition building opposing marketisation in housing and advocating the right to housing. With regard to activation policy we see some debate and nuance but less real policy difference between the various national policy and political actors (Oireachtas, 2015), albeit interviews suggest some senior civil servants privately resist what they consider an 'imposition', as do some policy experts who tried to raise objections to JobPath through NESC. Social partnership remains officially stood down but social partners were represented on the Labour Market Council (albeit employers have significantly more representation than trade unions suggesting shifts in power over the crisis). Political actors are relatively consistent over the period, trade union resistance to JobPath privatisation was negotiated through public sector arbitration systems. Community resitance to commissioing SICAP led to the significant reshaping of the second round of commissing and a more restricted quasi-market. Negative political impact associated with activation appears limited to self-inflicted wounds associated with JobBridge, a labour market internship and reforms to make lone parent payments conditional. While we see some civil society, media and movement protest against increased conditionality and JobPath, up to 2018 this has had little discernible impact on activation policy, albeit in February 2019 a parliamentary motion to abolish JobPath was passed and we see strong reaction to proposals to extend Pay by Results tenders to LESN and Job Clubs.

With regard to social housing, powerful international financial and property interests influenced and promoted a heavily marketised and increasingly financialised housing policy limiting rent controls, encouraging use of PPPs, and relaxing building regulations (Hearne, 2017). The private sector profited from maintaining the dominant position of the market as the preferred mechanism to deliver social housing. Despite strong policy inputs (NESC, 2013; Reynolds, 2017; Sirr, 2017), and despite powerful agency emerging to advocate for housing rights, power inequalities dominate housing policy. Government has resisted a 2013 Economic and Social Rights campaign which successfully 
brought their case for a constitutional right to housing through the 2015 Constitutional Convention. Instead policy continues to conservatively interpret the right to property in the 1937 Irish constitution as a veto on progressive housing regulation which might provide greater security of tenure. Providers of homeless services are, under the terms of their service delivery agreements or SLA's nuanced in advocacy about housing policy. Nonetheless a wider rental crisis (increases of 65\% from 2013 to 2017), and a dramatic increase of family homelessness since 2014, has led various actors to more forcefully contest the state's over-reliance on the private market. From 2015 small local grassroots housing action groups and campaigns such as the Home Sweet Home campaign in December 2016 have captured public imagination, a 2016 trade union supported campaign for 'fair and secure rents', while by late 2018 both Take Back the City and Raise the Roof were mobilising and contesting marketisation and articulating alternative rights-based narratives.

\section{Ideologies}

Ideas influence not only how problems are understood but also what policy alternatives, if any, are considered feasible (Pomey et al., 2010). Grover (2015) alerts us that involvement of the private sector is often framed by political and ideological discourse which promotes concepts of private, markets and individual or personal responsibility.

In general public discourse of both domestic and international actors reinforced the domestic preference for spending cuts over alternative avenues of increased revenue. However there are differences in timing. Earlier activation policy reforms parallel a period of strong international pressure and concentration of domestic power in the context of loan conditionality under the Troika, whose presence enabled Irish governments to implement unpopular reforms. Housing reforms were slower to evolve and were deliberated on and developed in a more domestic arena, without such a strong international input or context. At the same time, the power of the supervisory role of the European Central Bank is evident in fiscal rules limiting government borrowing, the discourse associated with austerity politically and practically limited development of policy alternatives.

In both sectors we see strong support for and discourse of marketisation, commissioning and procurement. However we find different experiences of opening up to markets. In the case of activation the state is still the primary delivery mechanism but is increasingly legitimating and using pay-byresults mechanisms to outsource specific services. Such privatisation occurred under the radar and by stealth, without significant public protest (Murphy, 2015). Dail and Oireachtas committee debates reference new public management language including commissioning, coherence and efficiencies however by late 2018 there is more focus on negative aspects of JobPath including 
sanctions and treatment of claimants. In contrast the attempt to marketise social housing has been over the radar, this policy orientation is sustained by a powerful political and media meta narrative that at once makes the market seem an inevitable and natural presence in social housing provision. Despite the reality that it fails to deliver housing outcomes we find the preference for marketisation of social housing is cognitively locked within state institutions and government (Niemelä \& Saarinen, 2012).

Public discourse also stigmatises claimants in both policy sectors. We see low key, but successful and significant shifts away from rights. Activation policy uses profiling and algorithms to target PES, alongside greater application of new sanctions and penalties and rules of engagement which require unemployed people to live in state of flex-insecurity. Homeless people are obliged to self-accommodate and obtain their own solutions to homelessness and to cope with increased insecurity, competition and discrimination associated with the shift from social housing to private rental housing tenure. With regard to activation the discourse has been one of Work-First Activation, and a broad anti-welfare and fraud control discourse had evolved under Labour Party leadership of DSP but increased considerably under Fine Gael leadership of DSP, albeit not to the level of the British tabloid press. The housing meta-narrative is mixed but sometimes injects elements of morality into public discourse where those who cannot access housing are made bear blame for market and policy failure. A creeping domestic-led discourse increasingly stigmatises those risk of homelessness questioning whether homeless families are 'gaming the system' to secure social housing. As with activation conditionality, the purpose of such discourse is to impose self-regulation, families have to successfully compete in the private market for what were once housing rights (Boland \& Griffin, 2015; Darmon \& Perez, 2011).

Ireland demonstrates capacity for double think and strategic ambiguity in political discourse, where expressions of neo-liberal policy preferences have tended to be 'concealed, piecemeal, serendipitous, pragmatic and consensual' (Kitchin, O'Callaghan, Boyle, Gleeson, \& Keaveney, 2012, p. 1306), leading to privatisation by stealth. However the scale of the water movement challenged the dominant hegemonic neoliberal consensus, showing potential for a more engaged citizenry who had a strong preference for the state-led provision of water services. While SLA's in third sector employment services and non-profit housing providers have a potentially chilling impact on advocacy, the recent articulation of rights-based claims in opposition to housing marketisation are evidence of alternative public discourse.

\section{Discussion}

The complex range of explanatory factors discussed below are best understood with the aid of the '3ls' framework which is used below to anchor 
issues as diverse as financial speculation, protest, the influence of domestic as well as international actors. We also draw attention here to the importance of examining timing within theories of policy change (Table 2 ).

While the ideational preference of the state for marketisaiton is consistent across the two sectors (Murphy \& Dukelow, 2016), there is a clear difference in the scale and type of marketisation pathways in the two sectors, with consequences for the state's capacity to control implementation of policy objectives. While there are some experiences in common, for example the chilling impact of use of SLA's to fund NGOs, we find in particular that the extent of financial speculation in the Irish housing market compromises the states capacity to meet social housing need through the private sector. We find less direct financial speculation in the Irish PES but recognise that private recruitment services have capacity to shape the states labour market policy capacity.

The Irish government engaged with activation and social housing reforms in the context of loan conditionality under a Troika bailout, however we find considerable government autonomy in policy design and scope in both policy areas. The 2009 collapse of existing national wage agreements and Ireland's

Table 2. Comparative black box framework: labour activation \& social housing reforms.

\begin{tabular}{|c|c|c|}
\hline Institutions & Activation (Intreo/JobPath) & Social housing rental subsidies \\
\hline \multicolumn{3}{|l|}{ Key variables } \\
\hline $\begin{array}{l}\text { Governance and } \\
\text { institutional policy } \\
\text { frame }\end{array}$ & $\begin{array}{l}\text { Pathways to Work } \\
\text { Quarterly targets, metrics, Report to } \\
\text { Labour Market Council } \\
\text { No local government } \\
\text { Vertical and horizontal governance } \\
\text { protocols }\end{array}$ & $\begin{array}{l}\text { Social Housing Strategy } 2020 \text { Support, } \\
\text { Supply and Reform (2014) Rebuilding } \\
\text { Ireland } \\
\text { Annual National Targets, Report to } \\
\text { national parliament } \\
\text { Local government implementation, } \\
\text { weak capacity }\end{array}$ \\
\hline $\begin{array}{l}\text { International } \\
\text { institutions } \\
\text { Interests }\end{array}$ & Troika target, OCED analysis, EU CSR's & SIP homeless analysis invisible \\
\hline $\begin{array}{l}\text { Political parties } \\
\text { Corporate actors } \\
\text { protest NGO/SM }\end{array}$ & $\begin{array}{l}\text { Indirect corporate actors (LMC) } \\
\text { No Social Movement } \\
\text { Oireachtas Committee, little } \\
\text { differentiation by political parties } \\
\text { NGO's as service delivery, weak and } \\
\text { little impact }\end{array}$ & $\begin{array}{l}\text { No direct corporate actors but } \\
\text { significant corporate influence } \\
\text { Small scale Social Movements } \\
\text { Oireachtas Committee influence, } \\
\text { some difference between political } \\
\text { parties. } \\
\text { NGO's as service delivery, mixed } \\
\text { policy impact }\end{array}$ \\
\hline International interests & $\begin{array}{l}\text { EU and OCED relevant to policy } \\
\text { learning and Troika implementation }\end{array}$ & REITS as lobby \\
\hline \multicolumn{3}{|c|}{ 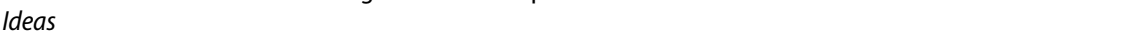 } \\
\hline $\begin{array}{l}\text { Debate/discourse } \\
\text { rights }\end{array}$ & $\begin{array}{l}\text { Work-First Activation, Anti-welfare, } \\
\text { fraud control, Sanctions and } \\
\text { Penalties, shift from rights }\end{array}$ & $\begin{array}{l}\text { Housing 'Crisis' } \\
\text { Frame of Right to housing, to home, } \\
\text { to city } \\
\text { Hubs, licences, institutionalisation }\end{array}$ \\
\hline $\begin{array}{l}\text { Debate/discourse } \\
\text { marketisation }\end{array}$ & $\begin{array}{l}\text { State primary, targets pay-by-results, } \\
\text { commissioning, value for money }\end{array}$ & $\begin{array}{l}\text { Home ownership, private property, } \\
\text { market recovery, market primary } \\
\text { mechanism } \\
\text { Global capital and finance }\end{array}$ \\
\hline
\end{tabular}


social partnership institutions removed vetoes making it easier to implement activation reforms, while social housing policy was less a central issue for pay bargaining. Ireland is now more highly centralised and stakeholders tend to impact reform agendas in the national policy context, where small policy communities maintain a policy consensus and, as interviews suggest, a degree of group-think. Local government were implementation actors in social housing policy while they were largely irrelevant to activation implementation. There appears alignment between all international, administrative and political elites but more so about the direction of labour activation than housing policy which is under a more sustained critique.

There was some political cost associated with two relatively peripheral activation issues and by 2019 JobPath and issues of privatisation are more often articulated as a public concern. Given the focus of the left over the years 2013-2016 has been on water policy, social housing policy has not been as salient an electoral issue as it might appear to be but this is likely to change in the next election, particularly as parties come under pressure from new housing grassroots movements with growing levels of protest about the role of the market in social housing and homeless policy.

Four factors appear most salient in explaining differences in implementation. Centralised power structures enabled a more consistent implementation of activation policy than private rental subsidy reform which was unevenly implemented across different local authorities. Where the two differed substantially was in the institutional architecture for implementation, with activation implemented from the top down through a highly centralised management team with a clear vertical line management. Social Housing build and acquisition targets were on other hand implemented (or not) by local authorities who reported to a central Department of Housing. Given their nature, housing reforms are also were slower to implement, driven through predominantly local domestic processes, they experience more domestic and local vetoes and are subject to a strong Irish tendency towards 'policy implementation paralysis'. Furthermore, capital spending for social housing was subject to drastic cuts in austerity reflecting not only fiscal rules, but also neoliberal support for marketisation of social housing policy.

A second point of departure in the policy infrastructure was the role of international actors including the Troika. International led policy learning or persuasion is evident in the activation policy field but international actors were 'pushing on an open door' (Dukelow, 2016) and, interviews suggest, were selectively amplified by domestic actors seeking room to manoeuvre to reshape activation policy. Activation reforms were facilitated by Troika implementation targets and reporting systems within a clear politically relevant reporting cycle. While the new rental subsidy HAP evolved in the context of the Troika the implementation period began after the Troika's departure with housing policy targets developed after the Troika departed. 
The third explanatory factor might be also be down to timing, this time in the domestic political system. Activation reforms were implemented in the context of strong national government while housing reforms suffered from the political turbulence of a minority coalition government, albeit one committed to all forms of marketisation. A fourth and most weighty explanatory factor appears to be the model and scale of marketisation and the degree to which it relates to financialisation. In activation policy we see a constricted creation of quasi-markets, limited to $€ 165 \mathrm{~m}$ per annum and across both profit and not for profit actors, albeit we acknowledge an underexplored private market for employment services which has lobbying power and practical capacity to influence the trajectory of the Irish labour market. In social housing we see a much more expansive forms of marketisation which is embedded in financialisation with potential benefits of $€ 1$ bn pa corporate subsidies through the HAP and a range of government funding, tax and legislative supports. While the state worked hard to entice international private actors into both markets it ultimately has more control over the form of contracted engagement in activation services than in the wild-west world of powerful residential capitalism. It is beyond the political capacity or desire of the state to regulate and tame powerful international housing actors to work in the interests of Irish society.

\section{Conclusion}

This paper used a 3l's framework to trace key ideas, institutions and interests and to isolate the dynamic informing two key policy decisions over the period 2010-2016. We conclude with some observations on the use of the 3l's framework which used three variables institutions, interests and ideologies to focus on similarities and differences between the two policies. While the 3l's framework proved useful in anchoring a wide range of variables it may be useful to think about how, in particular, international variables including the resource and ideational power of finance might be more fully built into the model. Having briefly sketched an overview of Irish political and policy architecture the paper largely compared two policies from a key point of policy formulation and tried to take the process through to policy implementation. This was more challenging than a strict 'point in time' comparison and two limitations are apparent. The interaction of the three variables will shift across the different stages of the policy cycle and this needs to be adequately factored into the analysis, for example local authorities may not be involved in the inception of the HAP but are involved in its implementation. Likewise the timing of the policy reform episode seems crucial. Pathways to Work, was implemented from 2012, in a period of strong united government and during the active Troika reporting schedule, senior public servants used this to traction to implement targets and resources. While only one year later, 
HAP is implemented by a minority government and appears to suffer from an absence of leadership and traction. These caveats aside, the findings in this article are of broader international and comparative relevance and demonstrate the complex relationship between 'policy and politic'. The comparative methodology facilitates a range of useful insights into the experiences of sector-specific pathways to privatisation with potential lessons for both policy makers and political actors. While we find evidence of inceasing resistance, we also find that different pathways to marketisation make it more difficult to observe the common trends across these policies, this makes it more difficult to join the dots and make connections across different policy areas, potentially making resistance less successful.

\section{Disclosure statement}

No potential conflict of interest was reported by the authors.

\section{Funding}

This work was supported by European Union's Horizon 2020 research and innovation programme under Grant Agreement No 649447.

\section{References}

Bentgsson, B. (2001). Housing as a social right: Implications for welfare state theory. Scandinavian Political Studies, 24(4), 25-275.

Boland, T., \& Griffin, R. (2015). The condition of unemployment: Appraising the impact of Ireland's new welfare policies. Waterford: Waterford Institute of Technology.

Boyle, N. (2005). FÁS and active labour market policy, 1985-2004. Studies in Public Policy No. 17. Dublin: The Policy Institute, Trinity College Dublin.

Burke Kennedy, E. (2017, November 6). Government will spend $€ 3$ bn on rent subsidies over next five years. Irish Times.

Darmon, I., \& Perez, C. (2011). "Conduct of conduct" or the shaping of adequate dispositions? Labour market and career guidance in four European countries. Critical Social Policy, 31(1), 77-101.

De la Porte, C., \& Pochet, P. (2012). Why and how (still) study the open method of coordination (OMC)? Journal of European Social Policy, 22(3), 336-349.

Department of Housing Environment and Local Government. (2014). Social housing strategy 2020: Support, supply and reform. Dublin: Government of Ireland.

Department of Housing, Planning and Local Government. (2016). Rebuilding Ireland. Dublin: Government of Ireland.

Department of Social Protection. (2012). Pathways to work. Dublin: DSP.

Dublin Regional Homeless Executive. (2017). Homeless data report. Dublin: DRHE.

Dukelow, F. (2016). 'Pushing against an open door': Reinforcing the neo-liberal policy paradigm in Ireland and the impact of EU intrusion. In C. De La Porte \& E. Heins (Eds.), The sovereign debt crisis, the EU and welfare state reform. Work and welfare in Europe (pp. 93-111). London: Palgrave Macmillan. 
Elsinga, M., Stephens, M., \& Knorr-Siedow, T. (2014). The privatisation of social housing: Three different pathways. In K. Scanlon, C. Whitehead, \& M. F. Arrigoitia (Eds.), Social housing in Europe (pp. 389-414). Chichester: Wiley Blackwell.

Epstein, G. A. (2005). Financialization and the world economy. Aldershot: Edward Elgar. Ferragina, E., \& Seelieb-Kaiser, M. (2011). Welfare regime debates: Past, present, futures? Policy and Politics, 39(4), 583-611.

Greve, B. (2015). Welfare and the welfare state, present and future. London: Routledge.

Grover, C. (2009). Privatising employment services in Britain. Critical Social Policy, 29(3), 487-509.

Grover, C. (2015). Social security policy and low wages in austere times. In Z. Irving, M. Fenger, \& J. Hudson (Eds.), Social policy review 27: Analysis and debate in social policy (pp. 33-54). London: Policy Press.

Grubb, D., Singh, S., \& Tergeist, P. (2009). Activation policies in Ireland. OECD Social, Employment and Migration Working Papers No. 75. Paris: OECD.

Hall, P., \& Taylor, R. (1996). Political science: The three new Institutionalisms. Political Studies, 44, 936-957.

Hardiman, N., \& Regan, A. (2012). The politics of austerity in Ireland. Intereconomics, 48 (I), 9-13.

Hay, C. (2004). Ideas, interests and institutions in the comparative economy of great transformations. Review of International Political Economy, 11(1), 204-226.

Hearne, R. (2017). A home or a wealth generator? Inequality, financialisation and the Irish housing crisis. Dublin: TASC.

Hearne, R., \& Murphy, M. (2017). Investing in the right to a home: Housing, HAPs and hubs. Kildare: Maynooth UniversityHearne R.

Hearne, R., \& Murphy, M. P. (2018). An absence of rights: Homeless families and social housing marketisation in Ireland. Administration, 66(2), 9-31.

Hermann, C. (2007). Neoliberalism in the EU (FORBA discussion paper 3/2007). Vienna: Forschungs- und Beratungsstelle Arbeitswelt.

IGEES. (2017, July). Analysis of current expenditure on housing supports. Dublin: Author. Ireland. (2010). Memorandum of understanding. Dublin: Stationery Office.

Kitchin, R., O'Callaghan, M., Boyle, M., Gleeson, J., \& Keaveney, K. (2012). Placing neoliberalism: The rise and fall of Ireland's Celtic Tiger. Environment and Planning A: Economy and Space, 44, 1302-1326.

Koppe, S. (2012). Making markets in the welfare state. The politics of varying market reforms. Journal of European Social Policy, 22(4), 446-447.

Labour Market Council. (2014). Interim report of the labour market council. Dublin: Stationery Office.

Lavelle, O., \& Callaghan, N. (2018). Spending review 2018 public employment services mapping activation. Dublin: IGEES.

Martin, J. (2014). Activation and active labour market policies in OECD countries: Stylized facts and evidence on their effectiveness (Geary Paper 6/2014 WP2014/09). Dublin: Geary Institute, University College Dublin.

McGuinness, S., O'Connell, P. J., Kelly, E., \& Walsh, J. R. (2011). Activation in Ireland: An evaluation of the national employment action plan (Research Series No. 20). Dublin: ESRI.

Meade, R. (2017, March 30). The re-signification of state-funded community development in Ireland: A problem of austerity and neoliberal government. Critical Social Policy. Retrieved from http://journals.sagepub.com/doi/abs/10.1177/0261018317701611

Minton, A. (2016). Capital: Who is London for? London: Penguin. 
Murphy, M. (2015, January). Privatisation kicks quietly and unquestioned. Village Magazine. Retrieved from https://villagemagazine.ie/index.php/2015/01/ privatisation-kicks-in-quietly-and-unquestioned/

Murphy, M. P., \& Dukelow, F. (2016). The Irish welfare state in the 21st century, challenges and change. London: Palgrave Mac Millan.

NESC, \& NESC. (2013). Activation report no. 8. Dublin: NESC.

Niemelä, M., \& Saarinen, A. (2012). The role of ideas and institutional change in Finnish public sector reform. Policy and Politics, 40(2), 171-191.

Noonan, M. (2013, January 30). Opening address by Minister for Finance Michael Noonan. TD at the Life and Pension Industry Conference, Department of Finance.

Norris, M., \& Byrne, M. (2016). Social housing's role in the Irish property boom and bust (Geary WP2016/15 November 21, 2016). Dublin: UCD.

O'Connell, P. J. (2016). Unemployment and labour market policy. In W. K. Roche, P. J. O'Connell, \& A. Prothero (Eds.), Austerity and recovery in Ireland Europe's poster child and the great recession (pp. 232-251). Oxford: OUP.

OECD. (2009). Privatisation in the 21st century: Recent experiences of OECD countries. Paris: OECD.

Oireachtas (2019). JobPath motion. Retrieved February 28, 2019, from https://www. oireachtas.ie/en/debates/debate/dail/2019-02-05/36/

Oireachtas Committee on Jobs, Social Protection and Activation. (2015). Debate on activation. Retrieved from http://oireachtasdebates.oireachtas.ie/

Pomey, M. P., Morgan, S., Church, J., Forest, P. G., Lavis, J. N., McIntoch, T., \& Dobson, S. (2010). Do provincial drug benefit initiatives create an effective policy lab? The evidence from Canada. Journal of Health Politics, Policy and Law, 35(5), 705-742.

Reynolds, M. (2017, April). State could save over $€ 9 b n$ over 30 years on social housing. Village Magazine.

Shearer, J. C., Abelson, J., Kouyaté, B., Lavis, J. N., \& Walt, G. (2016). Why do policies change? Institutions, interests, ideas and networks in three cases of policy reform. Health Policy and Planning, 31(9), 1200-1211.

Sirr, L. (2017, June 17). Housing panel TASC annual conference. Croke Park Conference Centre.

Taylor, T. (2015, August 28). Recruitment firms - they haven't gone away you know. Irish Times. Retrieved from https://www.irishtimes.com/business/work/recruitment-firmsthey-haven-t-gone-away-you-know-1.2330618

Taylor, R., Rees, J., \& Damm, L. (2016). UK employment services: Understanding provider strategies in a dynamic strategic action field. Policy \& Politics, 44(2), 253-267.

van der Zwan, N. (2014). Making sense of financialization. Socio-Economic Review, 12, 99-129.

Wiggan, J. (2015). What variety of employment service quasi-market? Ireland's JobPath as a private power market. In Z. Irving, M. Fenger, \& J. Hudson (Eds.), Social policy review 27 (pp. 151-165). Bristol: Policy Press. 